\title{
Pola Interaksi Edukatif dalam Metode Pembelajaran di Pesantren Khozinatul ‘Ulum Blora
}

\author{
Hamdan Adib* \\ UIN Prof KH Saifuddin Zuhri Purwokerto \\ Email: adib.hamdan123@gmail.com
}

\begin{abstract}
As one of the educational institutions in Indonesia, Islamic boarding schools also have methods in conveying material to their students and sometimes this method is a characteristic found in Islamic boarding schools. These various methods should be understood by taking into account the various patterns contained in them so that it can be seen to what extent the pesantren is actively involved in fostering good interaction between the kiai and the santri. The purpose of this study is to determine the pattern of educative interactions contained in the learning method at the Khozinatul 'Ulum Blora Islamic boarding school. This research is a field research carried out at the Khozinatul 'Ulum Blora Islamic Boarding School, the data collection techniques used are semi-structured interviews, participatory observation, and also documentation. The data obtained were then analyzed using Miles and Huberman's theory, namely data reduction, data display and data verification. The results of this study indicate that at the Khozinatul 'Ulum Blora Islamic boarding school in teaching material to students using five methods, namely memorization in which there is a two-way interaction pattern, bandongan in which there is a one-way interaction pattern and in the bahsul masa'il method, practice and play. role in which there is a pattern of multi-directional interaction.
\end{abstract}

Keywords: Educational Interaction, Method, Islamic Boarding School

\begin{abstract}
Abstrak
Sebagai salah satu lembaga pendidikan di Indonesia, pesantren juga memiliki metode dalam menyampaikan materi kepada santrinya dan terkadang metode ini menjadi ciri khas yang terdapat dalam pesantren. Berbagai metode ini mestinya dipahami dengan memperhatikan pola-pola interaksi edukatif yang terdapat di dalamnya sehingga bisa diketahui sejauh mana pesantren secara aktif menumbuhkan interaksi baik antara kiai dengan santri, pengurus dengan santri dan juga santri denagan santri. Tujuan penelitian ini yaitu untuk mengetahui pola interaksi edukatif yang terdapat dalam metode pembelajaran di pesantren Khozinatul Ulum Blora. Penelitian ini merupakan penelitian lapangan yang dilaksanakan di Pesantren Khozinatul 'Ulum Blora, teknik pengumpulan data yang digunakan adalah wawancara semi terstruktur, observasi partisipatif, dan juga dokumentasi. Data yang didapatkan kemudian dianalisis menggunakan teori milik Miles dan Huberman yaitu reduksi data, display data dan juga verifikasi data. Hasil penelitian ini menunjukkan bahwasannya di Pesantren Khozinatul 'Ulum Blora dalam mengajarkan materi kepada santri menggunakan lima metode yaitu hafalan dimana di dalamnya terdapat pola interaksi dua arah, bandongan dimana di dalamnya terdapat pola interaksi satu arah dan pada metode bahsul masa'il, praktik dan bermain peran di dalamnya terdapat pola interaksi multi arah.
\end{abstract}

Kata Kunci: Interaksi Edukatif, Metode, Pesantren 


\section{Pendahuluan}

Sampai saat ini pesantren merupakan basis pendidikan yang selalu mengalami perkembangan. Perkembangan pesantren diketahui dengan penambahan kelengkapan sarana dan prasarana pendidikan atau perubahan corak yang terdapat dalam diri pesantren itu sendiri. Manfred Ziemek dalam Umiarso membagi tipologi pesantren menjadi lima bentuk berdasarkan bangunan yang terdapat didalamnya yaitu 1) masjid dan rumah kiai, 2) masjid, rumah kiai dan pondok, 3) masjid, rumah kiai, pondok dan madrasah, 4) masjid, rumah kiai, pondok, madrasah dan tempat keterampilan, 5) masjid, rumah kiai, pondok, madrasah, tempat keterampilan, universitas, tempat pertemuan, tempat olahraga, dan sekolah formal. ${ }^{1}$

Tipologi lainnya juga diberikan oleh Takdir dimana dirinya menyebutkan bahwasannya tipologi pesantren terbagi ke dalam tiga bentuk yaitu tradisional, modern dan semi modern. ${ }^{2}$ Berbagai bentuk ini mempengaruhi metode pembelajaran yang terdapat di dalam pesantren itu sendiri, misalnya dalam bentuk tradisional pelaksanaan pembelajarannya hanya berpusat pada upaya dalam menerjemahkan dan mempelajari kitab kuning dengan menggunakan metode sorogan dan bandongan. ${ }^{3}$ Berbeda halnya dengan pesantren modern yang menerapkan berbagai metode dengan dasar menerapkan cara-cara lama yang baik dan mengakomodasi cara-cara baru yang lebih baik. Metode yang diterapkan di pesantren modern yaitu hafalan, demonstrasi, diskusi, dikte dan driil, resitasi, tanya jawab dan juga cermah. ${ }^{4}$

Sebagai pesantren yang termasuk ke dalam pesantren semi modern, Pesantren Khozinatul 'Ulum Blora juga menerapkan beberapa metode pembelajaran demi memberikan materi kepada santrinya melalui kegiatan yang dilaksanakan di pesantren, madrasah diniah dan juga sekolah formal. Selain itu pembelajaran ini dibarengi dengan penanaman nilai keIslaman berupa akhlak dan ketauhidan. Metodemetode tersebut dilakukan oleh kiai, ustadz dan juga pengurus yang diberi tugas untuk mengurus para santri.

Implementasi metode yang dilakukan memunculkan berbagai pola interaksi yang sangat beragam. Interaksi yang dilakukan dalam pembelajaran di pesantren ini dinamakan dengan interaksi edukatif. Interaksi edukatif ialah interaksi yang di dalamnya secara sadar memiliki tujuan yang mendidik, untuk mengantarkan siswa ke arah kedewasaannya. ${ }^{5}$ Terdapat batasan untuk memasukkan suatu interaksi ke dalam bentuk edukatif yaitu terdapat tujuan untuk mendidik dan mengantarkan santri menuju kearah kedewasaan sehingga tidak semua interaksi yang terjadi di pesantren merupakan interaksi edukatif.

\footnotetext{
${ }_{1}$ Umiarso, Kepemimpinan Transformasional Profetik Kajian Paradigmatik Ontos Integralistik Di Lembaga Pendidikan Islam (Jakarta: Kencana, 2018).

2 Mohammad Takdir, Modernisasi Kurikulum Pesantren Konsep Dan Metode Antroposentris, 1st ed. (Yogyakarta: IRCiSoD, 2018).

3 Faisal Kamal, "MODEL PEMBELAJARAN SOROGAN DAN BANDONGAN DALAM TRADISI PONDOK PESANTREN," PARAMUROBI: JURNAL PENDIDIKAN AGAMA ISLAM 3, no. 2 (2020): 15-26.

${ }^{4}$ Abdul Hakim and N Hani Herlina, "Manajemen Kurikulum Terpadu Di Pondok Pesantren Modern Daarul Huda Banjar," Jurnal Penelitian Pendidikan Islam,[SL] 6, no. 1 (2018): 111-32.

${ }^{5}$ Suryanti, Pengelolaan Pengajaran: Bintang Pustaka (Sleman: Bintang Pustaka Madani, 2020).
} 
Penelitian mengenai interaksi edukatif sebenarnya sudah pernah dilakukan oleh beberapa peneliti, misalnya Minhaji dimana dalam penelitiannya interaksi edukatif antara guru dan murid digunakan sebagai upaya dalam menanamkan nilai religius dan norma kehidupan, kemudian mengkategorisasikan pesantren, menjelaskan hubungan yang terdapat dalam guru dan santri dan perbedaan antara PPSS Situbondo, PPS Pasuruan dan PP al-Amien Sumenep. ${ }^{6}$ Kemudian penelitian Fauziah Desi Iriani dimana dalam penelitiannya menjelaskan bahwa di Pesantren Al Fatah Parakancanggah memiliki interaksi sosial yang bagus, hal ini terlihat dari strategi pendekatan yang dilakukan guru kepada siswanya. ${ }^{7}$

Terdapat perbedaan yang mendasar dalam penelitian ini dengan penelitian yang dilakukan oleh beberapa peneliti terdahulu, yang mana penelitian terdahulu memposisikan interaksi edukatif sebagai metode dan juga untuk melihat seberapa bagus interaksi edukatif yang dilakukan di suatu pesantren. Penelitian ini melihat pola yang terdapat dalam interaksi edukatif yang muncul dalam sutau metode pembelajaran.

Penelitian ini dirasa penting untuk dilakukan, karena dengan mengetahui pola interaksi yang terdapat dalam metode maka akan menginformasikan dominasi metode yang digunakan di Pesantren Khozinatul 'Ulum Blora dalam membentuk santri, apakah didominasi oleh metode yang memunculkan keaktifan santri atau malah sebaliknya. Penelitian ini bertujuan untuk mengetahui pola interaksi edukatif dalam metode pembelajaran yang diterapkan di Pesantren Khozinatul 'Ulum Blora. Metode yang digunakan dalam penelitian ini ialah kualitatif deskriptif.

Jenis penelitian yang dilakukan ialah penelitian lapangan atau field research dimana penelitian ini dilaksanakan di Pesantren Khozinatul 'Ulum Blora. Alasan dipilihnya Pesantren Khozinatul 'Ulum Blora sebagai lokasi penelitian disebabkan karena pesantren ini merupakan pesantren terbesar dan memiliki lembaga pendidikan terlengkap di kabupaten Blora sehingga segala kegiatan yang terdapat di dalamnya menjadi percontohan bagi pesantren-pesantren lainnya di kabupaten Blora.

Sebagai upaya dalam mendapatkan data penelitian, maka di dalam penelitian ini menggunakan tiga informan yaitu KH. A Zaki Fuad sebagai wakil pengasuh Pesantren Khozinatul 'Ulum Blora, Kiai Nur Rohim sebagai pembina Pesantren Khozinatul ‘Ulum Blora, Ahmad Nur Rokhim sebagai ketua santri putra Pesantren Khozinatul 'Ulum Blora dan Istianah sebagai ketua santri putri Pesantren Khozinatul 'Ulum Blora. Teknik pengumpulan data yang digunakan ialah wawancara semi terstruktur, observasi partisipatif dan dokumentasi. Setelah data terkumpul, maka dilanjutkan dengan menganalisis data yaitu dengan menggunakan teknik analisis data menurut Miles dan Huberman diawali dengan reduksi data, display data dan verifikasi data. ${ }^{8}$

${ }^{6}$ Minhaji Minhaji, “Interaksi Edukatif Dalam Membangun Pola Relasi Guru Dan Murid Di Pesantren: Studi Multi Kasus: PPSS Sukorejo Situbondo, PP Sidogiri Pasuruan Dan PP. Al-Amien Prenduan Sumenep" (UIN Sunan Ampel Surabaya, 2019).

${ }^{7}$ Fauziah Desi Iriani, "Interaksi Edukatif Guru Dan Siswa Madrasah Diniyah Di Pondok Pesanren AlFatah Parakancangah Banjarnegara" (Purwokerto: IAIN Purwokerto, 2017).

${ }^{8}$ Sugiyono, Metodologi Penelitian Kualitatif, Kuantitatif Dan RED (Bandung: Alfabeta, 2020). 


\section{Pembahasan}

\section{Gambaran Umum Pesantren Khozinatul 'Ulum Blora}

Pesantren Khozinatul 'Ulum Blora merupakan pesantren terbesar di kabupaten Blora yang diasuh oleh KH. Muharror Ali dan Hj. Umi Hani'. Pesantren ini memiliki 4 cabang pesantren lainnya yaitu Pesantren Khozinatul 'Ulum Al Azhar berafiliasi dengan MI Khozinatul 'Ulum, Pesantren Khozinatul 'Ulum An Nada berafiliasi dengan STAI Khozinatul Ulum, Pesantren Khozinatul ‘Ulum Al Mubarok berafiliasi dengan SMP IP Khozinatul Ulum, Pesantren Khozinatul 'Ulum An Nawa berafiliasi dengan PAUD Khozinatul Ulum, Pesantren Khozinatul 'Ulum Pusat yang berafiliasi dengan MTs dan juga MA. Namun semua lembaga pesantren dan lembaga yang berafiliasi dengan pesantren ini berada di bawah Yayasan Khozinatul 'Ulum Al Amin Blora. ${ }^{9}$

Pesantren yang didirikan pada 1981 di desa Mlangsen, Kecamatan Blora, Kabupaten Blora sebagai pusat dari pesantren dan Yayasan Khozinatul 'Ulum Al Amin Blora, sampai saat ini memiliki santri berjumlah 773 santri yang berasal dari pulau Jawa, Sumatra, Kalimantan dan pulau lainnya. ${ }^{10}$ Jika dilihat dari bentuknya, Pesantren Khozinatul 'Ulum Blora merupakan pesantren yang tergolong ke dalam bentuk semi modern. Pesantren semi modern sendiri diartikan dengan perpaduan antara pesantren tradisional dan modern dengan ciri yang terlihat melalui nilai-nilai tradisional yang masih kental dipegang teguh, kiai masih menempati posisi sentral, dan norma kode etik pesantren masih tetap menjadi standar pola pengembangan pesantren. ${ }^{11}$ Nasir dalam Adib menyebut pesantren sejenis Pesantren Khozinatul 'Ulum Blora ini sebagai pesantren berkembang dimana 30\% pembelajaran yang diberikan pada materi umum dan $70 \%$ pada pembelajaran agama dengan menambahkan sekolah diniah sesuai dengan keputusan SKB tiga mentri. ${ }^{12}$

Nilai tradisional di dalam Pesantren Khozinatul 'Ulum Blora diperlihatkan dengan masih kentalnya penggunaan kitab kuning sebagai referensi utama kajian, kepatuhan penuh kepada kiai dan ciri fisik berupa sarung dan kopiah yang masih dipertahankan. Selain itu lembaga pendidikan non formal seperti madrasah diniah mulai dari tingkat awaliah, wustha dan 'ulya juga melengkapi pendidikan yang dijalankan di pesantren. Metode-metode tradisional seperti bandongan, bahsul masa'il, hafalan juga menjadi metode yang masih dipertahankan. Namun pesantren ini juga tidak menutup diri akan adanya perubahan, hal ini dibuktikan dengan adanya lembaga pendidikan formal mulai dari PIAUD sampai dengan STAI, tersedianya lembaga keuangan syariah dan juga berbagai lembaga pengembangan diri milik pesantren. ${ }^{13}$

Pesantren Khozinatul 'Ulum Blora menggunakan kurikulum pesantren, kurikulum Departemen Agama dan Departemen Pendidikan Nasional yang dikemas menjadi tiga komponen terpadu yang di sesuaikan dengan kebutuhan, target, serta

${ }^{9}$ Hamdan Adib, “Dokumentasi Pesantren Khozinatul 'Ulum Blora” (2021).

${ }^{10}$ Adib.

${ }^{11}$ Takdir, Modernisasi Kurikulum Pesantren Konsep Dan Metode Antroposentris.

${ }^{12}$ Hamdan Adib, "Model Integrasi Islam, Sains Dan Budaya Pesantren," Misykah: Jurnal Pemikiran Dan Studi Islam 6, no. 2 (2021): 150-60.

${ }^{13}$ Adib, "Dokumentasi Pesantren Khozinatul 'Ulum Blora." 
pencapaiannya dalam menciptakan mutakharrijin yang sesuai dengan kebutuhan masyarakat. Hal ini disampaikan oleh Pembina Pesantren yang menyatakan bahwa kurikulum yang di pakai merupakan kurikulum terpadu yaitu penyatuan antara madrasah diniah dan madrasah formal serta pesantren yang bertujuan dalam mencapai satu tujuan yang serupa. ${ }^{14}$

\section{Pola Interaksi Edukatif dalam Metode Pembelajaran di Pesantren Khozinatul 'Ulum Blora}

Manusia merupakan individu yang membutuhkan individu lainnya dalam upaya pengembangan diri ataupun pemenuhan hasrat atau keinginan tertentu yang terdapat dalam diri. Hasrat ini bisa berupa keinginan untuk evaluasi, aktualisasi ataupun keinginan agar eksistensinya bisa diketahui oleh yang lainnya. Kebutuhan akan manusia lain ini dibuktikan dengan munculnya interaksi yang dilakukan manusia dengan manusia lainnya.

Interaksi juga dilakukan oleh ustadz dengan santri, pengurus dengan santri, santri dengan santri lainnya dengan berbagai macam tujuan yang ingin dicapai. Interaksi-interaksi ini bisa digolongkan menjadi dua bentuk, yaitu interaksi biasa dan interaksi edukatif. Interaksi biasa ialah interaksi yang dilakukan dalam kehidupan sehari-hari tidak memiliki tujuan pengembangan dan tidak terstruktur. Interaksi edukatif terjadi dalam suatu pembelajaran dimana interaksi edukatif merupakan hubungan timbal balik yang terjadi antara ustadz dan santri yang mengandung norma dan nilai yang disampaikan melalui sikap, pengetahuan dan keterampilan yang dapat membantu santri mendapatkan kompetensi yang ingin dicapai. ${ }^{15}$ Lebih jauh dijelaskan bahwasannya di dalam interaksi edukatif terdapat berbagai unsur yang harus dipenuhi yaitu: adanya materi yang menjadi inti pembahasan, tujuan yang ingin di capai jelas, adanya santri dan ustadz yang ikut dalam interaksi, adanya metode yang digunakan dalam mencapai tujuan, dilaksankan dalam ikatan situasional dan interaksi edukatif merupakan alat pendidikan. ${ }^{16}$ Melalui hal ini, dapat dipahami bahwasannya interaksi edukatif tidak hanya pelaksanaan pembelajaran ala kadarnya saja, namun pembelajaran yang diberikan kepada santri secara sistematis dan dilakukan dengan sungguh-sungguh.

Terjadinya interaksi edukatif menggambarkan adanya orang yang memberi dan menerima ilmu dalam suatu kondisi tertentu. Pemberian dan penerimaan materi ini tidak hanya dilakukan dengan memposisikan penerima sebagai penerima pasif, ada kalanya penerima materi memberikan feedback berupa pertanyaan ataupun eksplorasi yang dilakukan oleh sesama penerima sehingga di dalam suatu interaksi edukatif tidak hanya mencerminkan satu pola. Beberapa pendapat menjelaskan bahwasannya di dalam interaksi edukatif terdapat tiga pola: pertama, Interaksi satu arah, yaitu hubungan antara ustadz dengan santri di mana ustadz hanya berfungsi sebagai pemberi informasi tanpa adanya umpan balik (feedback) dari santri. Kedua, Interaksi dua arah yaitu hubungan antara ustadz dengan santri di mana ustadz

\footnotetext{
${ }^{14}$ Nur Rohim, "Wawancara” (2021).

15 Rifma, Optimalisasi Pembinaan Kompetensi Pedagodik Guru: Dilengkapi Model Pembinaan Kompetensi Pedagogik Guru (Jakarta: Kencana, 2016).

${ }^{16}$ M P I Nur Afif and Ansor Bahary, Tafsir Tarbawi: Pesan-Pesan Pendidikan Dalam Al-Quran (Tuban: Karya Litera Indonesia, 2020).
} 
memberi informasi sedang santri memberi umpan balik terhadap ustadz walau belum terdapat interaksi antara santri yang satu dengan santri lainnya. Ketiga, Interaksi multi arah yaitu hubungan ustadz dengan santri sudah lengkap di mana ustadz memberi informasi terhadap santri, santri juga memberi umpan balik bagi ustadz, demikian juga adanya umpan balik antara santri yang satu dengan santri yang lainnya. ${ }^{17}$

Ketiga pola interaksi ini juga terjadi pada metode pembelajaran di Pesantren Khozinatul 'Ulum Blora. Beberapa metode pembelajaran yang terdapat di pesantren Khozinatul 'Ulum Blora yang di dalamnya terdapat interaksi edukatif yaitu: pertama, metode hafalan. Metode hafalan digunakan untuk menghafalkan beberapa kitab kuning seperti Jurumiah, Nadhom Imriti, Alfiyah, Tasrifan Jombangan, Bulughul Marom dan juga Al-Qur'an Juz 30 beserta Tahlilnya. Bagi santri Tahfidz wajib menghafalkan 30 Juz Al-Qur'an beserta doa khatmil Qur'an yang terdapat dalam buku wirid khusus santri Pesantren Khozinatul 'Ulum Blora. ${ }^{18}$ Abror menjelaskan bahwasannya materi yang dijadikan bahan untuk dihafalkan biasanya berbentuk syair atau nadhzam, sebagai pelengkap metode hafalan sangat efetif untuk memelihara daya ingat santri terhadap materi yang dipelajari, karena dilakukan baik di dalam maupun di luar kelas. ${ }^{19}$

Selain itu metode hafalan juga digunakan untuk menghafalkan kosa kata baik bahasa Arab maupun bahasa Inggris. Hafalan ini sebagai bentuk kegiatan malam yaitu les bahasa yang bertujuan agar santri mampu menguasai bahasa Arab sebagai bahasa ibu pesantren dan bahasa Inggris sebagai bahasa internasional. Setelah santri menghafalkan berbagai macam hafalan yang dimiliki, maka kemudian santri menyetorkannya kepada ustadz dan sekaligus menjadi bahan penilaian ustadz terhadap kemampuan santri. Hal ini disampaikan oleh Pembina yang menjelaskan bahwasannya santri akan diberi beban untuk menghafalkan kitab kuning dan kemudian di setorkan kepada ustadz. Ada beberapa ustadz yang mensyaratkan terpenuhinya setoran ini ada yang tidak, jadi ketika materi di ujikan ada beberapa ustadz yang mengharuskan santri untuk menghafalkan materi yang sudah di sampaikan seperti Amsilatut Tasrifiah, Jurumiah, Imritihi dan juga Alfiyah. ${ }^{20}$

Jika dipahami dengan teori interaksi edukatif maka pola yang terjadi di dalam metode hafalan adalah pola dua arah. Hal ini disebabkan karena setelah santri menerima materi yang diintruksikan oleh ustadz, maka kemudian santri melanjutkannya untuk menghafalkan materi tersebut. Setelah materi dihafalkan, maka kemudian di setorkan kepada ustadz untuk membuktikan bahwa materi yang diberikan sudah dihafalkan dan sekaligus ustadz mengecek benar tidaknya hafalan santri.

Kedua, metode bandongan, metode bandongan dilakukan dengan cara ustadz membacakan serta menjelaskan isi kandungan kitab kuning, kemudian santri mendengarkan, menerima dan mencatat keterangan kiai di kitab kuning yang

${ }^{17}$ A H Nasution, F Tanjung, and M Iqbal, Kurikulum Dan Pembelajaran Sejarah (Medan: Yayasan Kita Menulis, 2020).

${ }^{18}$ Adib, "Dokumentasi Pesantren Khozinatul 'Ulum Blora."

${ }^{19}$ D Abror, Kurikulum Pesantren (Model Integrasi Pembelajaran Salaf Dan Khalaf) (Yogyakarta: Deepublish, 2020).

${ }^{20}$ A Zaki Fuad, “Wawancara” (2021). 
dimiliki. ${ }^{21}$ Metode bandongan di Pesantren Khozinatul ‘Ulum Blora dilakukan pada hari ahad pagi dimana seluruh santri baik putra maupun putri mengaji bersama kitab Tafsir Jalalain bersama Pengasuh di serambi masjid pondok. Metode ini juga digunakan hampir di seluruh pelajaran kitab kuning. Wakil Pengasuh menjelaskan bahwasannya metode bandongan merupakan ciri khas pesantren, maka tidak mungkin akan dihilangkan dan akan tetap selalu dipertahankan karena dalam metode ini pancaran keta'dziman santri akan terlihat. ${ }^{22}$

Melihat metode bandongan dengan kacamata pola interaksi edukatif, maka dapat diketahui bahwasannya metode ini menerapkan pola interaksi satu arah. Hal ini disebabkan dalam metode bandongan hanya ustadz yang berperan aktif dalam menyampaikan materi kepada santri, sedangkan santri hanya menerima materi dengan mencatat tanpa mempertanyakan apa yang disampaikan. Kebenaran materi yang disampaikan bersifat mutlak. Lebih jauh Tohar dan Lubis menjelaskan bahwasannya dalam metode bandongan ini ustadz berperan aktif sedangkan santri berperan pasif. ${ }^{23}$ Sebenarnya metode bandongan dengan memposisikan santri sebagai pendengar saja tidak menjadikan pembelajaran yang dilakukan menjadi aktif dan hidup. Riyadi menjelaskan bahwasannya jenis interaksi satu arah dominan dilakukan dalam suatu pembelajaran, berakibat pada kurang hidupnya kegiatan belajar yang dialami oleh siswa. ${ }^{24}$

Ketiga, metode bahsul masa'il merupakan metode yang pesertanya terdiri dari ustadz dan santri. dalam praktiknya metode ini digunakan untuk merespon, membahas dan mengkaji isu-isu tertentu dengan merujuk pada kitab-kitab besar lengkap dengan dalil dan metode penalaran hukum, sehingga metode ini sifatnya ilmiah. ${ }^{25}$ Metode bahsul masa'il di Pesantren Khozinatul 'Ulum Blora dilaksanakan ketika bahsul masa'il internal antar pesantren cabang dan pusat pada kegiatan haflah maulidiyah (peringatan maulid Nabi) serta pada kegiatan bahsul masail eksternal antar pondok pesantren Se-Kerasidenan Pati dan Bojonegoro pada kegiatan haflah akhirussanah (peringatan akhir tahun pesantren), hal ini disampaikan oleh ketua santri putra Pesantren Khozinatul 'Ulum Blora. ${ }^{26}$

Pola yang terjadi di dalam metode bahsul masa'il adalah pola interaksi multi arah. Interaksi multi arah memperlihatkan adanya pelibatan semua santri yang masing-masing tidak hanya bisa berinteraksi antara santri itu sendiri, tetapi mereka juga bisa berinteraksi dengan ustadz atau kiai. ${ }^{27}$ Pola interaksi ini berlaku dalam metode bahsul masa'il, hal ini disebabkan dalam metode bahsul masa'il terdapat santri, moderator dan juga musahih dimana mushahih adalah ustadz ataupun kiai. Posisi santri adalah yang membahas problematika yang diberikan oleh moderator dan kemudian

${ }^{21}$ Kholis Tohir and M. Syukri Azwar Lubis, MODEL PENDIDIKAN PESANTREN SALAFI (SCOPINDO MEDIA PUSTAKA, 2020).

${ }^{22}$ Fuad, "Wawancara."

${ }^{23}$ Tohir and Lubis, MODEL PENDIDIKAN PESANTREN SALAFI.

${ }^{24}$ I Riyadi, Model Pembelajaran Berbasis Metakognisi Untuk Peningkatan Kompetensi Siswa Pada Mata Pelajaran IPS (Yogyakarta: Deepublish, 2015).

${ }^{25}$ Sofyan, Catatan Pinggir Seorang Santri: 70 Tahun Drs. K.H. Rizali M. Noor (Inteligensia Media (Kelompok Penerbit Intrans Publishing), 2020).

${ }^{26}$ A Nur Rokhim, "Wawancara" (2021).

${ }^{27}$ Suharti et al., Strategi Belajar Mengajar (Surabaya: Jakad Media Publishing, 2020). 
kiai atau ustadz menjadi pengoreksi dan juga memberi pendapatnya berkaitan dengan permasalahan yang sedang dibahas. Permasalahan yang menjadi objek pembahasan biasanya mendapatkan satu titik temu ataupun beberapa titik temu yang kesemuanya memiliki dasar dari kitab-kitab yang besar.

Keempat, metode praktik, metode ini diartikan dengan metode pembelajaran untuk melatih dan meningkatkan kemampuan santri dalam mengaplikasikan pengetahuan dan keterampilan yang di dapatkan..$^{28}$ Metode praktik yang diterapkan di Pesantren Khozinatul ‘Ulum Blora digunakan dalam kegiatan yang sifatnya mengasah skill santri. Lebih jauh Ketua putra menjelaskan bahwasannya santri akan praktik langsung dalam kegiatan hadrah, seni baca Al-Qur'an, elektronika, desain grafis, fotografi dan videografi, pemanfaatan limbah menjadi pupuk dan paving. ${ }^{29}$ Dilaksanakannya metode dengan cara praktik secara langsung diharapkan materi yang dipraktikan akan melekat dalam ingatan dan perilaku santri sehingga tidak akan cepat memudar. Lubis menjelaskan bahwasannya praktik langsung memberikan pengaruh besar dan ilustrasinya menancap lebih kuat di hati dan memori santri. ${ }^{30}$

Pada metode praktik terlihat adanya satu atau lebih instruktur/pelatih yang membimbing santri dalam mengembangkan kemampuan yang dimilikinya. Beberapa pelatih ini menjelaskan dan mempraktikan secara langsung apa yang mesti di pelajari. Ketika santri tidak memahami suatu step atau materi maka dipersilahkan untuk bertanya dan diperbolehkan berkomunikasi dengan teman sesama pelatihan sehingga bisa dikatkan bahwasannya dalam metode ini pola interaksi yang tercermin adalah pola interaksi multi arah.

Kelima, metode bermain peran sering diartikan dengan metode yang melibatkan santri untuk berpura-pura menjadi seseorang dengan profesi tertentu yang digeluti orang tersebut. Selain itu peserta didik juga diminta untuk berpikir seperti orang tersebut agar dia dapat mempelajari tentang bagaimana menjadi seseorang dengan profesi tersebut. ${ }^{31}$ Simbolon juga menjelaskan bahwasannya bermain peran merupakan teknik bermain peran secara sederhana dimana santri dibagi untuk memerankan tokoh-tokoh tertentu sesuai dengan tema pelajaran. ${ }^{32}$ Metode dalam bermain peran juga digunakan dalam pelaksanaan pendidikan di Pesantren Khozinatul 'Ulum Blora. hal ini terlihat pada kegiatan khitabah dimana santri akan berperan sebagai siapapun yang menjadi tema pada kegiatan tersebut. Ketua santri putri menjelaskan bahwasannya santri akan berperan menjadi kiai, ustadz, ketua RT, mempelai pria dan wanita dan siapapun dalam kegiatan khitabah. ${ }^{33}$

Kegiatan dengan menggunakan metode bermain peran melibatkan santri dan juga pengurus. Pengurus sebagai santri senior memberikan materi atau tema yang

${ }^{28}$ Agus Supriyono et al., Kurikulum Presentasi Dengan Infografis (Jakarta: Bidang Perencanaan Diklat DPR RI, 2019).

${ }^{29}$ Rokhim, "Wawancara."

${ }^{30}$ Maulana Arafat Lubis, Pembelajaran Pendidikan Pancasila Dan Kewarganegaraan: (PPKN) DI SD/MI: Peluang Dan Tantangan Di Era Industri 4.0 (Jakarta: Prenada Media, 2020).

31 Pupu Saeful Rahmat, STRATEGI BELAJAR MENGAJAR (Surabaya: PT. SCOPINDO MEDIA PUSTAKA, 2019).

${ }^{32}$ Marlina Eliyanti Simbolon, TUTURAN DALAM PEMBELAJARAN BERBICARA DENGAN METODE RECIPROCAL TEACHING (Surabaya: MEDIA SAHABAT CENDEKIA, 2019).

${ }^{33}$ Istianah, "Wawancara” (2021). 
akan di bawakan oleh santri pada kegiatan khitabah. Jika dilihat lebih mendalam maka pola interaksi yang tercermin pada metode ini adalah interaksi multi arah, hal ini disebabkan karena santri akan selalu berinteraksi dengan pengurus misalnya pada tema peresmian masjid, walimatul urs ataupun tema lain yang membutuhkan penceramah dan pada kamar tersebut tidak memiliki sosok yang bisa memerankannya maka pengurus akan mencarikan orang lain untuk mengisi tokoh penceramah. Selain itu dalam menentukan tokoh dan melaksanakan kegiatan juga memerlukan koordinasi antar santri di kamar tersebut.

\section{Kesimpulan}

Pesantren Khozinatul 'Ulum Blora sebagai lembaga pendidikan non formal juga menerapkan berbagai metode yang digunakan untuk menyampaikan materi dan meningkatkan kemampuan santri. Berbagai metode ini yaitu metode hafalan, bandongan, bahsul masa'il, praktik dan metode bermain peran. Metode ini memiliki ciri khas tersendiri dalam penerapannya. Jika dilihat dari pola interaksi edukatif yang terdapat dalam metode antara santri dan ustadz maka bisa diketahui bahwasannya terdapat interaksi satu, dua dan multi arah.

Pola interaksi edukatif di setiap metode lebih jauh yaitu pada metode hafalan terjadi interaksi dua arah antara ustadz dan juga santri, pada metode bandongan terjadi interaksi satu arah dimana santri hanya pasif dan kiai atau ustadz berperan aktif dalam menyampaikan materi, pada metode bahsul masa'il terjadi interaksi multi arah baik antara santri dengan santri maupun santri dengan kiai begitu juga pada pelaksanaan metode praktik terjadi interaksi multi arah yang terjadi antara santri dan pelatih dan juga santri dengan santri. kemudian pada metode bermain peran terjadi interaksi antara santri dengan pengurus dan juga santri antar santri yang menggolongkan pada pola interaksi multi arah.

\section{Daftar Pustaka}

Abror, D. Kurikulum Pesantren (Model Integrasi Pembelajaran Salaf Dan Khalaf). Yogyakarta: Deepublish, 2020.

Adib, Hamdan. “Dokumentasi Pesantren Khozinatul 'Ulum Blora.” 2021.

- - - "Model Integrasi Islam, Sains Dan Budaya Pesantren.” Misykah: Jurnal Pemikiran Dan Studi Islam 6, no. 2 (2021): 150-60.

Fuad, A Zaki. “Wawancara.” 2021.

Hakim, Abdul, and N Hani Herlina. “Manajemen Kurikulum Terpadu Di Pondok Pesantren Modern Daarul Huda Banjar." Jurnal Penelitian Pendidikan Islam,[SL] 6, no. 1 (2018): 111-32. 
Iriani, Fauziah Desi. “Interaksi Edukatif Guru Dan Siswa Madrasah Diniyah Di Pondok Pesanren Al-Fatah Parakancangah Banjarnegara." Purwokerto: IAIN Purwokerto, 2017.

Istianah. “Wawancara." 2021.

Kamal, Faisal. “MODEL PEMBELAJARAN SOROGAN DAN BANDONGAN DALAM TRADISI PONDOK PESANTREN." PARAMUROBI: JURNAL PENDIDIKAN AGAMA ISLAM 3, no. 2 (2020): 15-26.

Maulana Arafat Lubis. Pembelajaran Pendidikan Pancasila Dan Kewarganegaraan: (PPKN) DI SD/MI: Peluang Dan Tantangan Di Era Industri 4.0. Jakarta: Prenada Media, 2020.

Minhaji, Minhaji. “Interaksi Edukatif Dalam Membangun Pola Relasi Guru Dan Murid Di Pesantren: Studi Multi Kasus: PPSS Sukorejo Situbondo, PP Sidogiri Pasuruan Dan PP. Al-Amien Prenduan Sumenep." UIN Sunan Ampel Surabaya, 2019.

Nasution, A H, F Tanjung, and M Iqbal. Kurikulum Dan Pembelajaran Sejarah. Medan: Yayasan Kita Menulis, 2020.

Nur Afif, M P I, and Ansor Bahary. Tafsir Tarbawi: Pesan-Pesan Pendidikan Dalam Al-Quran. Tuban: Karya Litera Indonesia, 2020.

Rahmat, Pupu Saeful. STRATEGI BELAJAR MENGAJAR. Surabaya: PT. SCOPINDO MEDIA PUSTAKA, 2019.

Rifma. Optimalisasi Pembinaan Kompetensi Pedagodik Guru: Dilengkapi Model Pembinaan Kompetensi Pedagogik Guru. Jakarta: Kencana, 2016.

Riyadi, I. Model Pembelajaran Berbasis Metakognisi Untuk Peningkatan Kompetensi Siswa Pada Mata Pelajaran IPS. Yogyakarta: Deepublish, 2015.

Rohim, Nur. “Wawancara." 2021.

Rokhim, A Nur. “Wawancara.” 2021.

Simbolon, Marlina Eliyanti. TUTURAN DALAM PEMBELAJARAN BERBICARA DENGAN METODE RECIPROCAL TEACHING. Surabaya: MEDIA SAHABAT CENDEKIA, 2019.

Sofyan. Catatan Pinggir Seorang Santri: 70 Tahun Drs. K.H. Rizali M. Noor. Inteligensia Media (Kelompok Penerbit Intrans Publishing), 2020. 
Sugiyono. Metodologi Penelitian Kualitatif, Kuantitatif Dan R\&D. Bandung: Alfabeta, 2020.

Suharti, Sumardi, Moh. Hanafi, and Hakim. Strategi Belajar Mengajar. Surabaya: Jakad Media Publishing, 2020.

Supriyono, Agus, Shanty Irma Idrus, Hani Yuliasih, Indra Cakra Buana, Ira Naomi Sihombing, Muhammad Haqiki Noviar, Hermawan Syarif, and Risa Tiarazani. Kurikulum Presentasi Dengan Infografis. Jakarta: Bidang Perencanaan Diklat DPR RI, 2019.

Suryanti. Pengelolaan Pengajaran: Bintang Pustaka. Sleman: Bintang Pustaka Madani, 2020.

Takdir, Mohammad. Modernisasi Kurikulum Pesantren Konsep Dan Metode Antroposentris. 1st ed. Yogyakarta: IRCiSoD, 2018.

Tohir, Kholis, and M. Syukri Azwar Lubis. MODEL PENDIDIKAN PESANTREN SALAFI. SCOPINDO MEDIA PUSTAKA, 2020.

Umiarso. Kepemimpinan Transformasional Profetik Kajian Paradigmatik Ontos Integralistik Di Lembaga Pendidikan Islam. Jakarta: Kencana, 2018. 